\title{
光加熱を用いる炭素繊維強化炭素複合材料の 二次元温度伝導率成分測定法 \\ Method to Measure Thermal Diffusivity Coefficients of 2 Dimensions for Carbon Fiber Reinforced Carbon Composites by Use of Light Heating
}

\author{
松島 栄次* \\ Eiji Matsushima
}

\begin{abstract}
炭素繊維強化炭素複合材料（C/C 複合材料）は高温で使用する構造材料として発展が期待 される先進複合材料である。 C/C 複合材料は異方性材料であり, その温度伝導率は 2 階テンソル量 （温度伝導率成分）となる。異方性材料を対象とした温度伝導率測定法は，異方性の主軸方向が既知 であることを前提とするものが多い，本研究は，主軸方向が未知である温度伝導率成分を測定するこ とを目的として，有限要素法による近似解を測定原理とする測定法を開発する．本報では，室温にお いて, 光加熱される $\mathrm{C} / \mathrm{C}$ 複合材料に対する二次元熱伝導実験による温度変化から温度伝導率成分を決 定することにより，測定法の健全性を実証する.
\end{abstract}

Carbon fiber reinforced carbon composites ( $\mathrm{C} / \mathrm{C}$ composites) have been important structural materials at high temperatures. $\mathrm{C} / \mathrm{C}$ composites are anisotropic solids and their thermal diffusivity is 2nd-order tensor of which components are called thermal diffusivity coefficients. The objective of study is to evaluate thermal diffusivity coefficients for an anisotropic material of which diad axes (such that a rotation of 180 degrees about them brings the structure into a position congruous with its original one) are unknown using stepwise light heating method in which the finite element method (FEM) is used for data reduction. This report describes experiments conducted to confirm a principle for the anisotropic material at room temperature and thermal diffusivity coefficients measured for metals and $\mathrm{C} / \mathrm{C}$ composites which are cut from a plate at some angles with the direction of fiber.

[Keywords: C/C composites, thermal diffusivity, method to measure, finite element method]

\section{1.はじめに}

炭素繊維強化炭素複合材料 (C/C 複合材料) は，炭素繊 維, 炭素材料および気孔により構成される. それは異方性 材料であり，Carslaw と Jaeger[1]によれば，温度伝導率が 2 階テンソル量（温度伝導率成分）となる. その温度伝導 率評価方法は, 構成要素の温度伝導率を測定し, その分布 を観測して有効温度伝導率を算出する方法[2] 伝導率を測定する方法がある. 本研究では後者について検 討する.

佐藤ら[3]は, レーザーフラッシュ法を用いて, 三次元織 $\mathrm{C} / \mathrm{C}$ 複合材料に対して繊維と平行方向の温度伝導率を測定 している. 入澤ら[4]は, フィルム状炭素繊維強化プラスチ ック（CFRP）を炭素化した C/C 複合材料を作成し，その 面方向の熱伝導率をレーザーフラッシュ法により測定して

* 大阪工業大学工学部機械工学科,

干535-8585 大阪市旭区大宮 5-16-1.

Dept. of Mechanical Engineering, Fac. of Engineering, Osaka Institute of Technology, 5-16-1 Asahi-ku, Osaka 535-8585.

FAX: 06-6957-2134, E-mail: eiji.matsushima@oit.ac.jp
いる．これらは，異方性の主軸方向における温度伝導率を 測定し，座標変換により温度伝導率成分を評価するもので あり，主軸方向が既知であることを前提とする．栗原ら[5] は, レーザースポット周期加熱法を用いて, 温度の観測位 置を増やすことにより, 炭素繊維強化プラスチック (CFRP) における面内方向の熱的異方性を評価する装置を開発して いる. 根本[6]は, レーザパルス状点熱源加熱法を用いて, 雲母材の主軸温度伝導率および主軸角を同時に測定してい る.これらは，異方性材料の主軸方向が未知の場合におい て, 温度伝導率成分を評価するものである.

今後, $\mathrm{C} / \mathrm{C}$ 複合材料の応用範囲が拡大され, 繊維織物に おける繊維の配向方向が複雑になることが予想される。 そ の際，主軸方向を特定して温度伝導率を測定することが困 難になり, 栗原ら[5]や根本[6]の研究は重要になるものと 考えられる. そこで, 本研究では, ステップ状加熱法[7]を 用いて, 温度の観測位置を増やすことにより, 温度伝導率 成分を測定することを目的とする，なお，ステップ状加熱 法は, 荒木ら[8]により溶融塩の測定に適用されて以降, $\mathrm{C} / \mathrm{C}$ 複合材料に応用される研究例はなく, それにより温度 
伝導率成分が測定される研究例もない.

本報では，二次元温度伝導率成分を測定することを目的 として，有限要素法による近似解を測定原理とし，ステッ プ状光加熱を用いた温度伝導率成分測定法を開発する。 そ こで, $\mathrm{Ti}$ と $\mathrm{C} / \mathrm{C}$ 複合材料に対する室温における熱伝導実 験により観測される温度の時間変化を一次元熱伝導に対す る稂密解と比較して，温度伝導率を決定する方法と，それ を二次元熱伝導に対する近似解と比較して，二次元温度伝 導率成分を決定する方法の健全性を実証する。

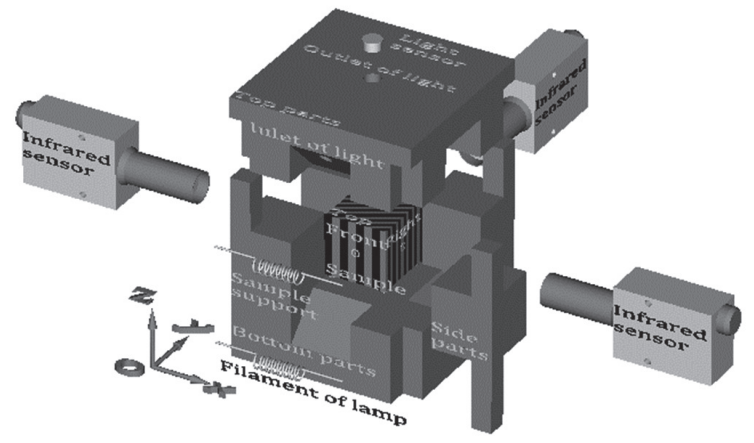

Fig. 1 Principle to measure a thermal diffusivity.

\section{2. 測定原理}

図1に，前面（Front）が加熱され，左面（Left），右面 (Right) および後面 (Back) の温度が観測される測定原理 図を示す．光源はランプのフィラメント（白色螺旋形状） 2個である. 直方体試料 (死色と黒色の縞模様) は，その前 面のみに光が照射されるように，試料支持部品（灰色）に より囲まれる（図では，試料が現れるように，上部品が上 側に，右前部品が右側にずらされている）。温度は，加熱 面を除く 3 面の中心座標を中心とする直径 $4 \mathrm{~mm}$ の円形面積 (試料前面の丸印) における平均值として赤外線温度計(白 色と圧色の2色）3個により観測される. 光は試料支持上部 品の前面側にある穴から入射し，上部品上側にある穴から 光検出素子 (白色) に導か氺, 光強度の時間変化が観測さ れる. この光強度の時間変化にしたがって加熱される系に 対する熱伝導現象から温度伝導率が決定される. その熱伝 導方程式の解から計算されるひとつの位置における温度の 時間変化において，ひとつの時刻における温度に対するそ の他の時刻における温度の比は，加熱強度に関係なく，温 度伝導率の関数となる。したがって, 最適化法を用いて, 材料の温度に対する観測值と, 厳密解あるいは近似解によ る解析值との差が最小になるように, 温度伝導率が決定さ れる. 最適化法には逐次シンプレックス探索法[9]を用いる.

\section{1 一次元熱伝導 (㛜密解)}

2. 1 . 1 順解析

測定対象に対して，次の仮定をする. (a) 熱伝導は材料 厚み方向の一次元現象である. (b) 熱物性は均質か等方 性である. (c) 初期温度は材料内とその周囲で一様である. (d) 境界は材料前面と後面であり，それらは周囲から断熱 される. (e) 表面熱流束は材料前面に一様に分布し，時間 に対して階段関数状に変化する.この場合，熱伝導方程式 は,

$$
\frac{\partial T}{\partial t}-a \frac{\partial^{2} T}{\partial y^{2}}=0
$$

である。また，初期温度は，

$$
[T]_{t=0}=0,
$$

であり，境界条件は，

$$
\left[k \frac{\partial T}{\partial y}+q_{0} \delta(y) q_{e}(t)\right]_{y=0}=0,\left[k \frac{\partial T}{\partial y}\right]_{y=l_{y}}=0,
$$

である．さらに，表面熱流束は，

$$
\boldsymbol{q}_{h}(y, t)=q_{0} \delta(y) q_{e}(t) \boldsymbol{j}
$$

と表せる.ここで， $q_{e}$ は光検出素子で観測される光強度の 時間変化である. 式(1)の峳密解は， $y$ 軸に垂直な一面 $(y=$ $\psi\rangle$ に瞬閒熱源 $(t=\tau)$ が発生する場合のGreen関数[1],

$$
\begin{aligned}
& G(y, t ; \psi, \tau) \\
& \quad=\frac{1}{l_{y}}\left\{1+2 \sum_{n=1}^{\infty} \cos \left(\beta_{n} y\right) \cos \left(\beta_{n} \psi\right) e^{-a \beta_{n}^{2}(t-\tau)}\right\},
\end{aligned}
$$

を用いて,

$$
T(y, t)=\frac{q_{0}}{\rho c} \int_{0}^{t}\left[\delta(\psi) q_{e}(\tau) G(y, t ; \psi, \tau)\right]_{\psi=0} \mathrm{~d} \tau,
$$


と表される.ただし，座標系の原点は材料前面とし，

$$
\beta_{n}=\frac{n \pi}{l_{y}}
$$

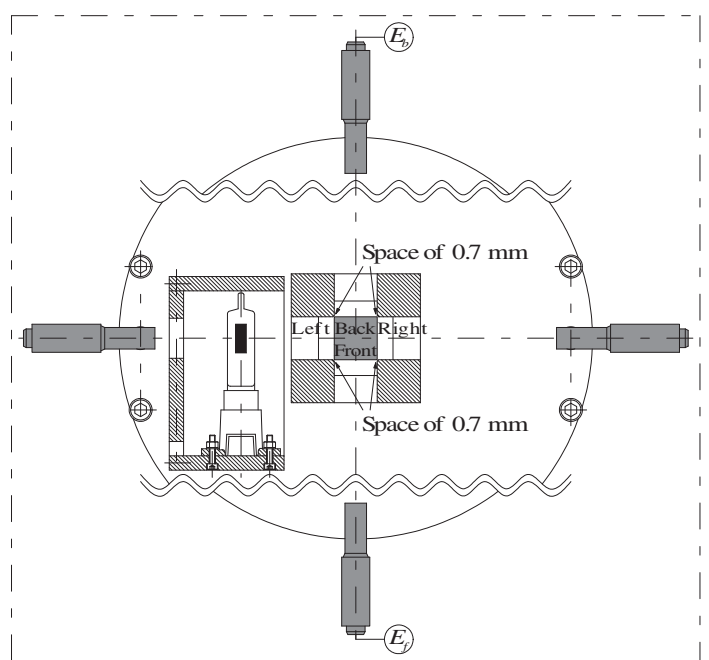

(a) Test section with sectional views from top

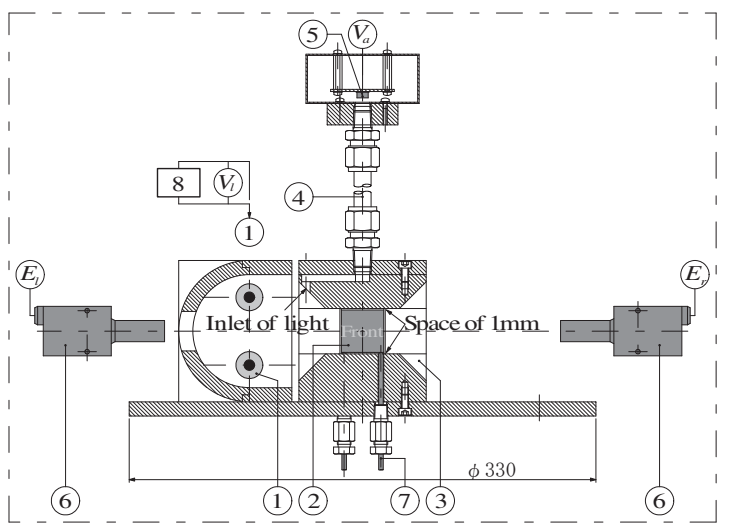

(b) Test section with sectional views from front

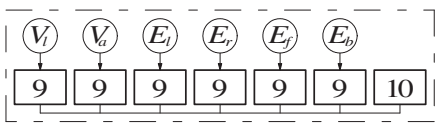

(c) Measuring system

Fig. 2 Schematic diagram of the experimental apparatus. 1, luminous source; 2 , sample; 3 , sample support; 4 , conduit tube of light; 5, light sensor; 6, infrared sensor at left, right, front and back; 7, thermocouple; 8, transformer; 9, digital multi-meter; 10, personal computer; $V_{a}$, voltage of light sensor; $V_{l}$, Voltage of transformer at left; $E_{l}, E_{r}, E_{f}$ and $E_{b}$, amperage of infrared sensor at left, right, front and back.
である.

\section{1.2 逆解析}

ひとつの位置における温度に対する観測值 $T_{e}\left(y, t_{i}\right)$ と解析 值 $T_{a}\left(y, t_{i}\right)$ との差から計算される標準偏差 $S_{T}$,

$$
s_{T}^{2}=\frac{1}{m-1} \sum_{i=1}^{m}\left\{T_{e}\left(y, t_{i}\right)-T_{a}\left(y, t_{i}\right)\right\}^{2},
$$

が最小になる温度伝導率が決定される。ここで, $t_{i}$ と $m$ は, それぞれ，温度の記録時間と記録数である.

\section{2 二次元熱伝導 (近似解)}

\section{2. 1 順解析}

測定対象に対して，次の仮定をする. (a) 熱伝導は材料 幅方向と厚み方向の二次元現象とする. (b) 熱物性は均質 な異方性とする。 (c) 初期温度は材料内とその周囲で一様 である. (d) 境界は材料左面, 右面, 前面および後面であ り，それらは周囲から断熱される。（e）表面熱流束は材料 前面に一様に分布し, 時間に対して階段関数状に変化する. この場合, 熱伝導方程式は,

$$
\frac{\partial T}{\partial t}+\vec{\nabla} \cdot \frac{\boldsymbol{q}}{\rho c}=0, \quad \vec{\nabla}=\left[\begin{array}{c}
\frac{\partial}{\partial x} \\
\frac{\partial}{\partial y}
\end{array}\right]
$$

である.ここで,

$\frac{\boldsymbol{q}}{\rho c}=-\boldsymbol{a} \vec{\nabla} T=-\left[\begin{array}{ll}a_{x x} & a_{x y} \\ a_{y x} & a_{y y}\end{array}\right]\left[\begin{array}{l}\frac{\partial T}{\partial x} \\ \frac{\partial T}{\partial y}\end{array}\right], \quad a_{x y}=a_{y x}$,

であり，温度伝導率を対称2階テンソル量とする。また，初 期温度は，式(2)と等しく，境界条件は，

$$
\left[\boldsymbol{q} \cdot \boldsymbol{n}-\boldsymbol{q}_{h} \cdot \boldsymbol{n}\right]_{\text {boundary }}=0,
$$

となる. 一方, 表面熱流束は, 


$$
\boldsymbol{q}_{h}(x, y, t)=q_{0}\left\{u(x, 0)-u\left(x, l_{x}\right)\right\} \delta(y) q_{e}(t) \boldsymbol{j},
$$

と表せる. ただし, 座標系の原点は, 材料左前の角とする. 式(9)の熱伝導方程式を, 有限要素法 (FEM) のひとつであ る Galerkin法により空間に関して離散化し，CrankNicolson差分により時間に関して離散化する[10]．要素は 三角形1次要素である. 順解析における要素数は 512 , 節点 数は289および時間増分は1/6sである.

\section{2.2 逆解析}

ひとつの位置における温度に対する観測值 $T_{e}\left(x, y, t_{i}\right)$ と解 析值 $T_{a}\left(x, y, t_{i}\right)$ との差加計算される標準偏差 $s_{T}$ を,

$$
s_{T}^{2}=\frac{1}{m-1} \sum_{i=1}^{m}\left\{T_{e}\left(x, y, t_{i}\right)-T_{a}\left(x, y, t_{i}\right)\right\}^{2},
$$

とする. 前面が加熱される実験に対して計算される左面 $((x$, $\left.y)=\left(0, l_{y} / 2\right)\right)$, 右面 $\left((x, y)=\left(l_{x}, l_{y} / 2\right)\right)$ および後面 $((x, y)=$ $\left.\left(l_{x} / 2, l_{y}\right)\right)$ における標準偏差, 左面が加熱される実験に対し て計算される右面，前面 $\left((x, y)=\left(l_{x} / 2,0\right)\right)$ および後面にお ける標準偏差の総和が最小になる温度伝導率成分が決定さ れる。

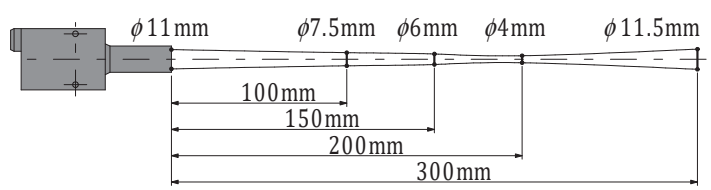

Fig. 3 Observed range of vision by an infrared sensor.

\section{3. 実験方法と試料}

\section{1 実験方法}

図 2 に, 左面が加熱され，右面，前面および後面の温度 が観測される実験系統図を示す。実験装置には, 変圧器, 試験部および測定系がある. 試験部は, 光源, 試料, クロ メル/アルメル熱電対 (JIS 規格 K 型熱電対), 光検出素子 および赤外線温度計により構成される. 光源は八ロゲンラ ンプであり，そのフィラメントは螺旋形状 (図 1 参照) で 外径が $7.4 \mathrm{~mm}$ で長さが $20 \mathrm{~mm}$ である. $\mathrm{K}$ 型熱電対は直径 $1.6 \mathrm{~mm}$ の金属シース接地形であり,その先端が試料支持下 部品から $1 \mathrm{~mm}$ だけ突出している. 試料は，K型熱電刘に よって支持され，試料支持部品と接触する部分は熱電対先 端のみである. 光検出素子はシリコンフォトダイオードで
あり,それにより光強度の時間変化が観測される.図 3 に, 赤外線温度計の観測視野を示す，その観測視野は，先端か ら $200 \mathrm{~mm}$ の距離で直径 $4 \mathrm{~mm}$ の円形面積となる．赤外線 温度計は，試料の右面，前面および後面の温度を観測する よう固定部品により配置され, その出力電流は, $0 \sim 1350^{\circ} \mathrm{C}$ の温度範囲が 4〜 20mA となるように調整されている．測 定系は，デジタルマルチメータとパーソナルコンピュータ で構成される. 光検出素子の出力電圧と赤外線温度計の出 力電流は, $1 / 6 \mathrm{~s}$ 間隔で観測され, それぞれ, 分解能が $0.1 \mu \mathrm{V}$

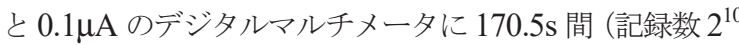
個）記録される．K 型熱電対の温度は，10s 間隔で観測さ れ，温度の分解能が $0.1 \mathrm{~K}$ のデータロガーに記録される. 実験では，まず，光源への負荷電圧を $0 \mathrm{~V}$ に保ち，試料の 温度が定常となる状態（定常状態）を観測する. 次に，負 荷電圧を変化させずに，試料の初期温度（初期状態）を観 測する，そして，負荷電圧を階段関数状（ステップ状）に 増加（変圧器の電圧を $0 \mathrm{~V}$ から $80 \mathrm{~V}$ 程度に増加）させて, 試料の温度が初期温度から変化する状態（加熱状態）を観 測する．なお，光検出素子と赤外線温度計により観測され る初期状態における光強度と温度の標準偏差は, それぞれ， $25 \mathrm{pW}$ と $0.27 \mathrm{~K}$ (電流值, $3.2 \mu \mathrm{A}$ ) である. また, ひとつ の試料に対して，前面を加熱する実験と左面を加熱する実 験は，それぞれ，3 回繰返される．その際，赤外線温度計 の位置は変更されない.

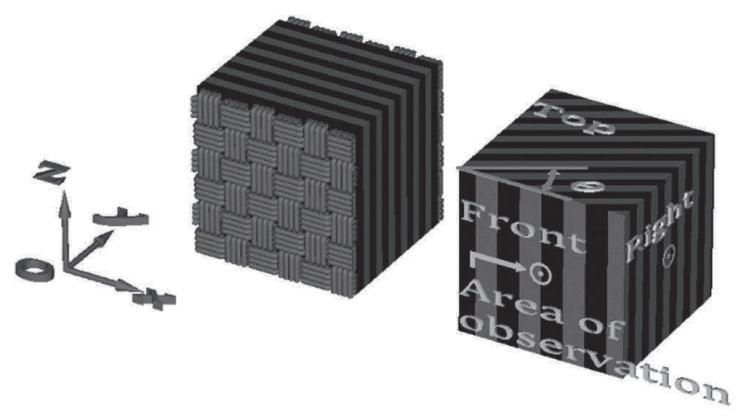

Fig. 4 Sample of $\mathrm{C} / \mathrm{C}$ composites.

\section{2 試料}

等方性材料はチタン（Ti）である．Ti は，JIS 規格の種 類が 2 種（純度 $99.42 \%$ 以上）に準ずる丸棒から切り出さ れた試料である。 また，その表面は黒体塗料が塗られる。 $\mathrm{C} / \mathrm{C}$ 複合材料は，日本カーボン㑣製 CCM-190C である. 図 4 左図のように，炭素繊維は織物面内で直角に交差する ように配向される（図では，炭素繊維の線径と織物の厚み が拡大されている）が，厚み方向には配向されない，板材 
では, 繊維の方向が織物毎にランダムになるように, 炭素 繊維織物が積層される。したがって, CCM-190C の熱物性 は, 織物面と平行な面 $(x z$ 面) 内で等方性であり, 織物面 に垂直な面 $(x y$ 面) 内で直交異方性になるものと考えられ る. 図 4 右図のように, 試料は, 板材から織物面と前面と の角度 $\theta\left(0^{\circ}, 20^{\circ}, 30^{\circ}\right.$ および $\left.45^{\circ}\right)$ をつけて切り出 される，ただし，個々の試料は，その製造工程は同じであ るが, 単一の板材から切り出されたものではない. 表 1 に, 試料の寸法と標準偏差 $s_{L}$ を示す.

Table 1 Size $[\mathrm{mm}]$ and the standard deviation, $s_{L}[\mathrm{~mm}]$ for samples.

\begin{tabular}{|c|c|c|c|c|}
\hline Materials & Values & Width & Thickness & Height \\
\hline \multirow{2}{*}{$\mathrm{Ti}$} & Average & 30.08 & 30.03 & 30.06 \\
\hline $\mathrm{C} / \mathrm{C}$ & $s_{L}$ & 0.005 & 0.014 & 0.009 \\
\hline$\theta=0^{\circ}$ & Average & 29.98 & 29.96 & 29.78 \\
\hline $\mathrm{C} / \mathrm{C}$ & $s_{L}$ & 0.065 & 0.020 & 0.078 \\
$\theta=20^{\circ}$ & Average & 29.99 & 30.13 & 29.98 \\
\hline $\mathrm{C} / \mathrm{C}$ & $s_{L}$ & 0.070 & 0.079 & 0.186 \\
$\theta=30^{\circ}$ & Average & 30.07 & 30.04 & 29.93 \\
\hline $\mathrm{C} / \mathrm{C}$ & $s_{L}$ & 0.073 & 0.040 & 0.043 \\
$\theta=45^{\circ}$ & Average & 30.05 & 30.00 & 29.98 \\
\hline & $s_{L}$ & 0.046 & 0.020 & 0.018 \\
\hline
\end{tabular}

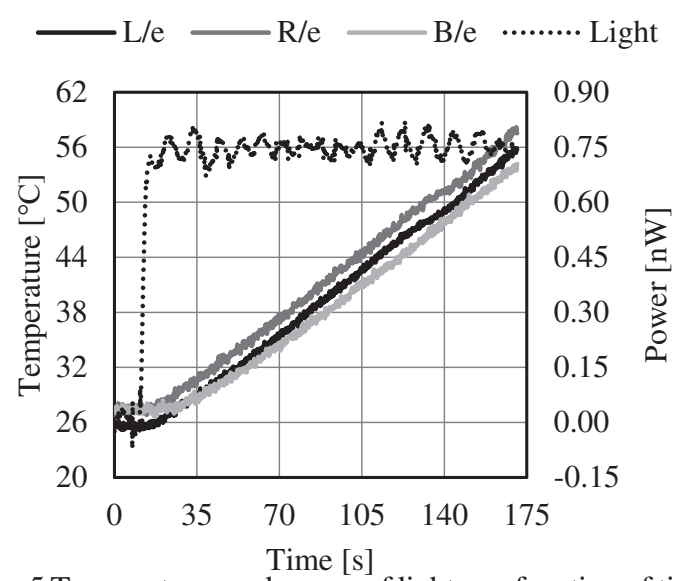

Fig. 5 Temperatures and power of light as a function of time for Ti when sample is heated at front surface. L, R and B are respectively left, right and back surfaces and e means data for experiments.

\section{4. 結果と考察}

\section{4. $1 \mathrm{Ti}$}

図 5 に, 前面が加熱される実験で, 観測される左面, 右 面および後面における温度の時間変化（以下，温度履歴と いう, 実線) と光強度の時間变化（点線）を示す. 光強度 は約 10 後に階段関数状に増加するが, その増加前に電気
的雑音と考えられる強度変化と, 増加後に振幅が $0.07 \mathrm{nW}$ で周期が $10 \mathrm{~s}$ 程の電源電力変動による強度変化が含まれる. 順解析には, 増加前後の強度変化も入力される. また, 左 面と右面における温度には, 約 $130 \mathrm{~s}$ 後に自然対流が原因 と考えられる変化[7]が観測されるため, 逆解析には 0s か ら $85.2 \mathrm{~s}$ (記録数 $2^{9}$ 個) の間で観測される温度を入力する.

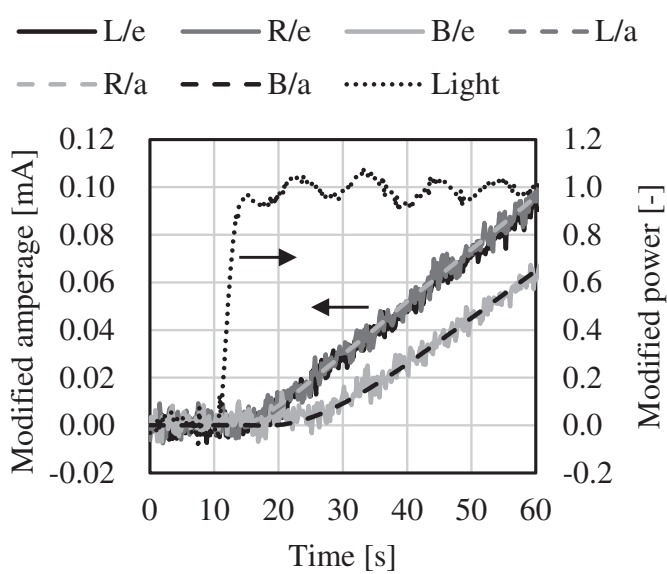

(a) When sample is heated at front surface

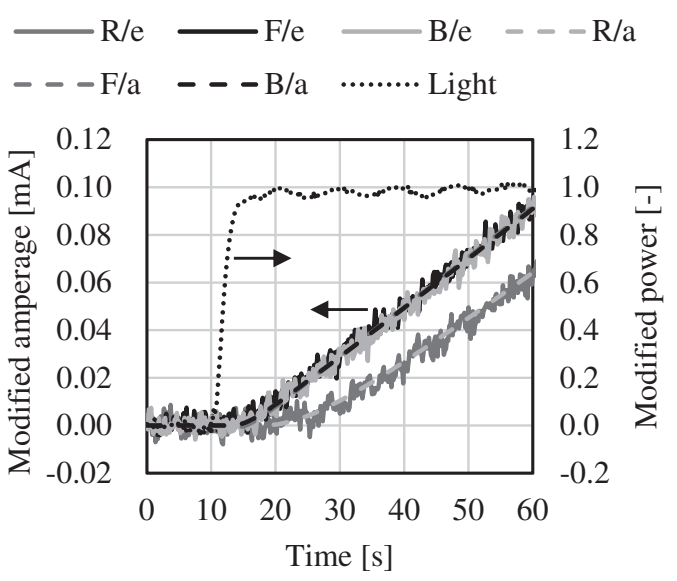

(b) When sample is heated at left surface

Fig. 6 Modified amperage of infrared sensor and modified power of light as a function of time for Ti. F is front surface and a means data for analyses of FEM.

図 6(a)に, 前面が加熱される実験で, 観測される左面, 右面および後面における温度履歴（実線）と光強度の時間 変化 $q_{e}$ (点線) を示寸. 光強度は, 階段関数状に増加する 前における $0 \mathrm{~s}$ から $2.5 \mathrm{~s}$ （記録数 $2^{4}$ 個）の平均值が 0 , 増 加した後における $82.7 \mathrm{~s}$ から $85.2 \mathrm{~s}$ の平均值が 1 となるよ うに無次元化され, 順解析に入力される. 温度履歴は, 図 5 にみられる $2 \mathrm{~K}$ 程度の初期温度差を無くして, 初期温度 
からの温度上昇量が電流值で表され, 逆解析に入力される. 左面と右面における温度はほぼ等しく, 二次元温度伝導率 成分の $a_{x y}$ がゼロになることを示す. すべての温度は, 光強 度増加後から数 $\mathrm{s}$ の間, 変化しない時間（以下，時間遅れ という）があり，その後，下に凸な曲線を描きながら上昇 する. 左面と右面の時間遅れは, 後面のそれよりも短い. また, すべての温度は, 数十 $\mathrm{s}$ 以後, 直線的に上昇するこ とから, 試料表面が断熱的であることが確認される[7].さ らに，加熱中における前面温度分布をサーモグラフィで観 測し，ほぼ面内は一様温度分布となることを確認した。 図 6(b)に, 左面が加熱される実験で, 観測される右面, 前面 および後面における温度履歴と光強度の時間変化を示す。 前面と後面における温度履歴はほぼ等しく, 前面が加熱さ れる実験における左面と右面のそれらと等しい，右面にお ける温度履歴は前面が加熱される実験における後面のそれ と等しい. これは, 二次元温度伝導率成分の $a_{x x}$ と $a_{y y}$ が等 しいことを示す. 図6から, Ti が等方性材料であることが 確認される.

Table 2 Thermal diffusivity $\left[\mathrm{mm}^{2} / \mathrm{s}\right]$ on assumption of one dimension, the error [\%] from reference $[11]\left[\mathrm{mm}^{2} / \mathrm{s}\right]$ and the standard deviation, $s_{D}\left[\mathrm{~mm}^{2} / \mathrm{s}\right]$ for Ti.

\begin{tabular}{|c|c|c|c|c|c|}
\hline Heated & Observed & Average & Error & $\overline{s_{D}}$ & Ref. \\
\hline \multirow{4}{*}{ Front } & Left & 12.5 & 35 & 0.43 & \multirow{8}{*}{9.25} \\
\hline & Right & 8.85 & -4.3 & 0.92 & \\
\hline & Back & 9.95 & 7.6 & 0.85 & \\
\hline & Average & 10.4 & 13 & 1.85 & \\
\hline \multirow{4}{*}{ Left } & Right & 9.63 & 4.1 & 0.10 & \\
\hline & Front & 12.4 & 34 & 0.19 & \\
\hline & Back & 9.70 & 4.9 & 0.60 & \\
\hline & Average & 10.6 & 14 & 1.55 & \\
\hline
\end{tabular}

表 2 に, 図 6 の温度履歴と一次元熱伝導における厳密解 を順解析とする逆解析によって決定される温度伝導率の平 均値, 文献值との誤差および標準偏差 $s_{D}$ を示す. 表中

「Average」行の值は, 観測 3 面における温度伝導率の平 均值, 文献值との誤差および標準偏差である. 前面加熱に よる温度伝導率の平均值, 誤差および標準偏差は, 左面加 熱によるそれらとほぼ等しく, 文献值は標準偏差の範囲内 にある. ただし，前面加熱で左面観測による温度伝導率と 左面加熱で前面観測によるそれの誤差はその他に比べて大 きい，これは，赤外線温度計の観測軸が加熱面側にずれる ことや観測軸と試料面が垂直ではないことなどが原因であ ると考えられる. しかし, 本報の実験装置は, この誤差の 原因を制御できないため, これらを偶然誤差と考える.今 後, 本方法の精度を向上させるためには, その原因を制御 できる実験装置に改良する必要がある.
表 3 には, 図 6 の温度履歴と二次元熱伝導における近似 解を順解析とする逆解析によって決定される温度伝導率成 分とその行列式の平方根 $\left(|\boldsymbol{a}|^{0.5}\right.$, 以下, 大きさという) を示 す. $a_{x y}$ はほぼゼロとなり， $a_{x x}, a_{y y}$ および $\left.\boldsymbol{a}\right|^{0.5}$ はほぼ等し く, 表 2 の偶然誤差の範囲内にある. 図 6 には, 決定され る温度伝導率成分によって計算される温度履歴の解析値

（破線）も示寸，同図から，解析值は観測值と良く一致す ることと, 光強度に含まれる電気的雑音と電源電力変動に よる強度変化は, 階段状変化に対して $10 \%$ 程度の大きさで あるため, 温度履歴の解析值に影響を与えないことが確認 される.

Table 3 Thermal diffusivity $\left[\mathrm{mm}^{2} / \mathrm{s}\right]$ on assumption of two dimensions, the error [\%] from reference $[11]\left[\mathrm{mm}^{2} / \mathrm{s}\right]$ and the standard deviation, $s_{D}\left[\mathrm{~mm}^{2} / \mathrm{s}\right]$ for Ti.

\begin{tabular}{|r|r|r|r|r|r|}
\hline Materials & $\boldsymbol{a}$ & Average & Error & \multicolumn{1}{c|}{$s_{D}$} & Ref. \\
\hline \multirow{4}{*}{$\mathrm{Ti}$} & $a_{x x}$ & 9.46 & 2.3 & 0.47 & 9.25 \\
\cline { 2 - 6 } & $a_{x y}$ & 8.62 & & 2.5 & 0 \\
\cline { 2 - 6 } & $a_{y y}$ & $9.70^{-4}$ & & $\times 10^{-4}$ & 0 \\
\cline { 2 - 6 } & $|\boldsymbol{a}|^{0.5}$ & 9.59 & 3.4 & 0.55 & 9.25 \\
\hline
\end{tabular}

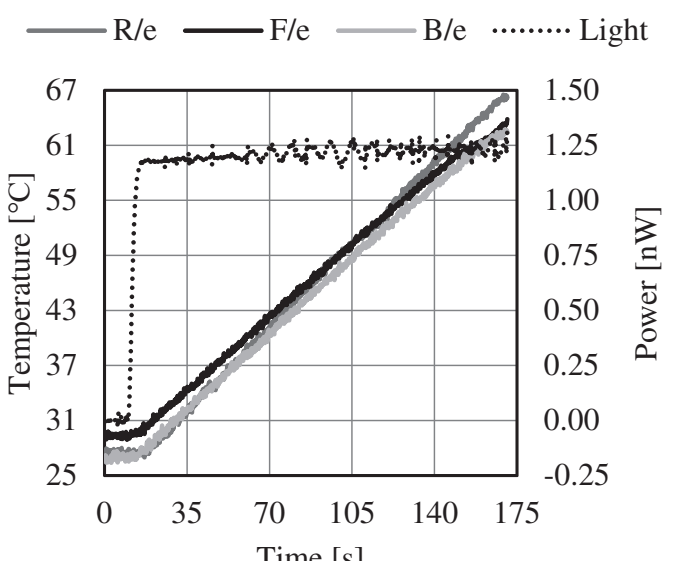

Fig. 7 Temperatures and power of light as a function of time for $\mathrm{C} / \mathrm{C}$ composite of $\theta=0$ degrees when sample is heated at left surface.

\section{4. $2 \mathrm{C} / \mathrm{C}$ 複合材料}

4. 2. $1 \theta=0^{\circ}$

図 7 に, 左面が加熱される実験で, 観測される右面, 前 面および後面における温度履歴と光強度の時間変化を示す. 光強度は, 約 $10 \mathrm{~s}$ 後に階段関数状に増加するが, Ti と同様 に増加前に電気的雑音と考えられる強度変化と, 増加後に 電源電力変動による強度変化が含まれる. 順解析には, 増 加前後の強度変化も入力される. また, 右面と前面におけ る温度には, 約 $100 \mathrm{~s}$ 後に自然対流によるものと考えられ 
る変化[7]が観測されるため, 逆解析には 0s から $85.2 \mathrm{~s}$ (記 録数 $2^{9}$ 個）の間で観測される温度を入力する.

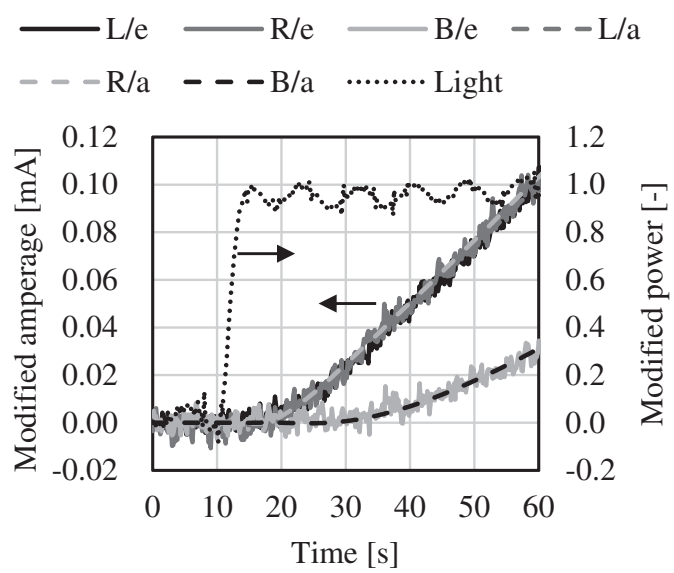

(a) When sample is heated at front surface

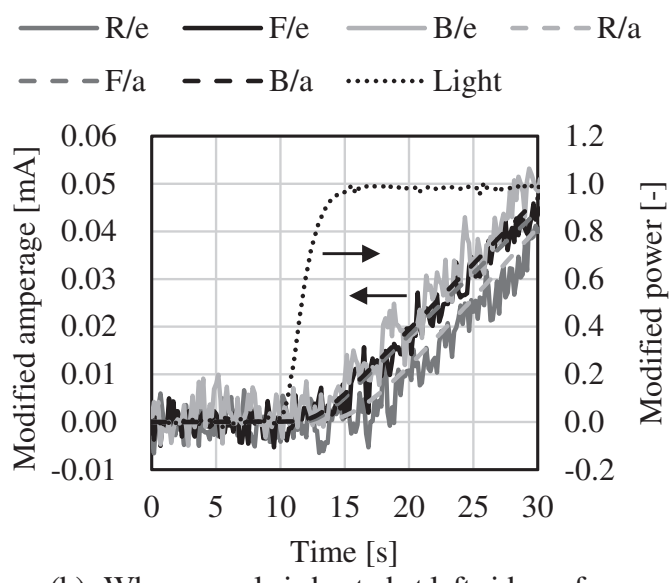

(b) When sample is heated at left side surface

Fig. 8 Modified amperage of infrared sensor and modified power of light as a function of time for $\mathrm{C} / \mathrm{C}$ composite of $\theta$ $=0$ degrees.

図 8(a)に, 前面が加熱される実験で, 観測される温度履 歴と光強度の時間変化を示寸. 左面, 右面および後面にお ける温度履歴は Ti のそれとほぼ等しいが, それらの時間遅 れは Ti のそれより長い.これは $a_{x y}$ がゼロとなり, $a_{y y}$ が Ti のそれよりも小さくなることを示す. 図 8(b)に, 左面が加 熱される実験で, 観測される温度履歴と光強度の時間変化 を示す. 右面, 前面および後面における温度履歴は Ti のそ れとほぼ等しいが，それらの時間遅れは Ti のそれより短 い.これは $a_{x x}$ が Ti のそれよりも大きくなることを示す。 また, すべての温度は, 数十 $\mathrm{s}$ 以後, 直線的に上昇するこ とから, 試料表面が断熱的であることが確認される[7]. 図
8 は, 温度伝導率の主軸が式(10)のフーリエの法則におい て定義される座標軸に一致する異方性材料の性質を示す。

Table 4 Thermal diffusivity $\left[\mathrm{mm}^{2} / \mathrm{s}\right]$ on assumption of one dimension, the error [\%] from reference [12] $\left[\mathrm{mm}^{2} / \mathrm{s}\right]$ and the standard deviation, $s_{D}\left[\mathrm{~mm}^{2} / \mathrm{s}\right]$ for C/C composite of $\theta=$ 0 degrees.

\begin{tabular}{|c|c|c|c|c|c|}
\hline Heated & Observed & Average & Error & $s_{D}$ & Ref. \\
\hline \multirow{4}{*}{ Front } & Left & 3.88 & 12 & 0.37 & \multirow{4}{*}{$\begin{array}{l}3.47 \\
(\perp)\end{array}$} \\
\hline & Right & 3.76 & 8.4 & 0.61 & \\
\hline & Back & 3.93 & 13 & 0.03 & \\
\hline & Average & 3.87 & 11 & 0.09 & \\
\hline \multirow{4}{*}{ Left } & Right & 26.5 & 22 & 2.0 & \multirow{4}{*}{$\begin{array}{l}21.7 \\
\text { (II) }\end{array}$} \\
\hline & Front & 29.2 & 35 & 2.2 & \\
\hline & Back & 33.3 & 54 & 4.5 & \\
\hline & Average & 29.7 & 37 & 3.5 & \\
\hline
\end{tabular}

Table 5 Thermal diffusivity $\left[\mathrm{mm}^{2} / \mathrm{s}\right]$ on assumption of two dimensions, the error [\%] from reference [12] $\left[\mathrm{mm}^{2} / \mathrm{s}\right]$ and the standard deviation, $s_{D}\left[\mathrm{~mm}^{2} / \mathrm{s}\right]$ for $\mathrm{C} / \mathrm{C}$ composites.

\begin{tabular}{|c|c|c|c|c|c|}
\hline Materials & $a$ & Average & Error & $\overrightarrow{s_{D}}$ & Ref. \\
\hline \multirow{4}{*}{$\begin{array}{r}\mathrm{C} / \mathrm{C} \\
\theta=0^{\circ}\end{array}$} & $a_{x x}$ & 31.9 & 47 & 1.00 & 21.7 \\
\hline & $a_{x y}$ & $\begin{array}{r}2.06 \\
\times 10^{-2}\end{array}$ & & $\begin{array}{r}1.7 \\
\times 10^{-2}\end{array}$ & 0 \\
\hline & $a_{y y}$ & 4.19 & 21 & 0.22 & 3.47 \\
\hline & $|\boldsymbol{a}|^{0.5}$ & 11.6 & 33 & 0.25 & 8.68 \\
\hline \multirow{4}{*}{$\begin{array}{c}\mathrm{C} / \mathrm{C} \\
\theta=20^{\circ}\end{array}$} & $a_{x x}$ & 17.4 & -11 & 0.95 & 19.6 \\
\hline & $a_{x y}$ & 4.54 & -23 & 0.18 & 5.86 \\
\hline & $a_{y y}$ & 4.01 & -28 & 0.16 & 5.60 \\
\hline & $|\boldsymbol{a}|^{0.5}$ & 7.00 & -19 & 0.17 & 8.68 \\
\hline \multirow{4}{*}{$\begin{array}{r}\mathrm{C} / \mathrm{C} \\
\theta=30^{\circ}\end{array}$} & $a_{x x}$ & 13.3 & -23 & 0.44 & 17.1 \\
\hline & $a_{x y}$ & 5.74 & -27 & 0.20 & 7.89 \\
\hline & $a_{y y}$ & 6.56 & -18 & 0.40 & 8.03 \\
\hline & $|\boldsymbol{a}|^{0.5}$ & 7.35 & -15 & 0.33 & 8.68 \\
\hline \multirow{4}{*}{$\begin{array}{c}\mathrm{C} / \mathrm{C} \\
\theta=45^{\circ}\end{array}$} & $a_{x x}$ & 16.0 & 27 & 0.44 & 12.6 \\
\hline & $a_{x y}$ & 11.4 & 25 & 0.41 & 9.12 \\
\hline & $a_{y y}$ & 16.1 & 28 & 1.07 & 12.6 \\
\hline & $|\boldsymbol{a}|^{0.5}$ & 11.3 & 30 & 0.25 & 8.68 \\
\hline
\end{tabular}

表 4 に, 図 8 の温度履歴と一次元熱伝導における厳密解 を順解析とする逆解析によって決定される温度伝導率を示 す. 表 5 に, 図 8 の温度履歴と二次元熱伝導における近似 解を順解析と寸る逆解析によって決定される温度伝導率成 分とその大きさを示す. $a_{x y}$ はほぼゼロとなり $, a_{x x}(\|), a_{y y}$ ( ）および $|\boldsymbol{a}|^{0.5}$ はすべて異なる. ほとんどの温度伝導率は 文献值よりも大きく, 文献值は測定值の標準偏差内にない. そこで，温度伝導率成分の大きさと異方性割合とを区別す るため, 無次元温度伝導率 $\boldsymbol{a}^{*}$,

$$
\boldsymbol{a}^{*} \equiv\left[\begin{array}{ll}
a_{x x}^{*} & a_{x y}^{*} \\
a_{y x}^{*} & a_{y y}^{*}
\end{array}\right]=\frac{\boldsymbol{a}}{|\boldsymbol{a}|^{0.5}}, \quad a_{x y}^{*}=a_{y x}^{*},
$$


を求めると, 表 6 となる. 無次元温度伝導率成分の文献值 は，標準偏差の範囲内にないが，その誤差は表 2 の偶然誤 差の範囲内である. 図 8 には, 決定される温度伝導率成分 によって計算される温度履歴の解析值も示寸. 同図から, 解析值は観測值と良く一致寸ることと, 光強度に含まれる 電気的雑音と電源電力変動による強度変化は, 階段状変化 に対して $10 \%$ 程度の大きさであるため, 温度履歴の解析值 に影響を与えないことが確認される。

Table 6 Thermal diffusivity on assumption of two dimensions, the error [\%] from reference [12] and the standard deviation without dimension for $\mathrm{C} / \mathrm{C}$ composites.

\begin{tabular}{|c|c|r|r|r|r|}
\hline Materials & $a^{*}$ & Average & Error & \multicolumn{1}{c|}{$s_{D}$} & \multicolumn{1}{c|}{ Ref. } \\
\hline \multirow{2}{*}{$\begin{array}{c}\text { C/C } \\
\theta=0\end{array}$} & $a_{x x}{ }^{\circ}$ & 2.76 & 10 & 0.104 & 2.50 \\
& $a_{x y}{ }^{*}$ & 1.76 & & 1.47 & 0 \\
& $a_{y y}{ }^{*}$ & 0.363 & -9.3 & 0.014 & 0.400 \\
\hline \multirow{2}{*}{$\mathrm{C} / \mathrm{C}$} & $a_{x x}{ }^{*}$ & 2.48 & 10 & 0.076 & 2.25 \\
$\theta=20^{\circ}$ & $a_{x y}{ }^{*}$ & 0.649 & -3.9 & 0.035 & 0.675 \\
& $a_{y y}{ }^{*}$ & 0.573 & -11 & 0.035 & 0.646 \\
\hline \multirow{2}{*}{$\mathrm{C} / \mathrm{C}$} & $a_{x x}{ }^{*}$ & 1.81 & -8.6 & 0.048 & 1.98 \\
$\theta=30^{\circ}$ & $a_{x y}{ }^{*}$ & 0.782 & -14 & 0.012 & 0.910 \\
\cline { 2 - 6 } & $a_{y y}{ }^{*}$ & 0.892 & -3.5 & 0.026 & 0.925 \\
\hline \multirow{2}{*}{$\mathrm{C} / \mathrm{C}$} & $a_{x x}{ }^{*}$ & 1.42 & -2.3 & 0.045 & 1.45 \\
\cline { 2 - 6 }$\theta=45^{\circ}$ & $a_{x y}{ }^{*}$ & 1.01 & -3.7 & 0.036 & 1.05 \\
\cline { 2 - 6 } & $a_{y y}{ }^{*}$ & 1.43 & -1.4 & 0.087 & 1.45 \\
\hline
\end{tabular}

\section{4. $2.2 \theta=30^{\circ}$}

図9(a)に，前面が加熱される実験で，観測される温度履 歴と光強度の時間変化を示寸. 右面における温度は, 数 $\mathrm{s}$ の間, 時間遅れがあり, その後下に凸な曲線を描きながら 上昇し, 次に上に凸な曲線を描きながら上昇して, 数十 $\mathrm{s}$ 以後は直線的に上昇する. 左面と後面における温度は, 数 十 $\mathrm{s}$ 程度の時間遅れがあり, その後下に凸な曲線を描きな がら上昇し, 数十 $\mathrm{s}$ 以後は直線的に上昇する. 左面と右面 における温度履歴は一致せず，等方性材料のそれらとは異 なる.これは $a_{x y}$ がゼロにならないことを示す．時間遅れ は, 右面, 左面および後面の順で長くなる. 図9(b)に, 左 面が加熱される実験で, 観測される温度履歴と光強度の時 間変化を示す. 後面における温度履歴は前面が加熱される 実験における右面のそれと同様であり, 右面と前面におけ る温度履歴は前面が加熱される実験における左面と後面の それらと同様である，時間遅れは，後面，右面および前面
の順で長くなるが, それぞれ, 前面が加熱される実験にお ける右面，左面および後面の時間遅れよりも短い。これは $a_{x x}$ が $a_{y y}$ より大きくなることを示す. 図 9 は, 温度伝導率 の主軸が式(10)のフーリエの法則において定義される座標 軸に一致しない異方性材料の性質を示す. これらの温度履 歴と二次元熱伝導における近似解を順解析とする逆解析に よって決定される温度伝導率成分を表 5 に, $\theta=20^{\circ}$ の結 果と合わせて示す. なお, 表 5 の文献值は, $\theta=0^{\circ}$ の温度 伝導率成分に $z$ 軸を中心とする座標変換,

$$
\boldsymbol{a}=\left[\begin{array}{cc}
\cos \theta & \sin \theta \\
-\sin \theta & \cos \theta
\end{array}\right]^{-1}\left[\begin{array}{cc}
21.7 & 0 \\
0 & 3.47
\end{array}\right]\left[\begin{array}{cc}
\cos \theta & \sin \theta \\
-\sin \theta & \cos \theta
\end{array}\right],
$$

を適用して算出される值である. $\theta=20^{\circ}$ と $\theta=30^{\circ}$ の試 料では, 温度伝導率成分とその大きさはすべて文献值より も小さく, その誤差は標準偏差よりも大きい. $\theta=20^{\circ}$ の 大きさと $\theta=30^{\circ}$ のそれは, 標準偏差の範囲に共通する值 がある. 表 6 の無次元温度伝導率成分の文献值は, 標準偏 差の範囲内にないが，その誤差は表 2 の偶然誤差の範囲内 である.よって，その大きさが試料毎の個体差により異な るものと考えられる. また, 図 9 に示寸温度履歴の解析值 は観測值と良く一致する.

\section{2 . $3 \theta=45^{\circ}$}

図 10(a)に, 前面が加熱される実験で, 観測される温度履 歴と光強度の時間変化を示す. すべての面における温度履 歴は, $\theta=30^{\circ}$ の $\mathrm{C} / \mathrm{C}$ 複合材料におけるそれらと同様であ るが, 左面における温度履歴と後面におけるそれがほぼ等 しい. 右面の時間遅れは左面（後面）のそれより短い. 図 10(b)に, 左面が加熱される実験で, 観測される温度履歴と 光強度の時間変化を示す.すべての面における温度履歴は, $\theta=30^{\circ}$ の $\mathrm{C} / \mathrm{C}$ 複合材料におけるそれらと同様であるが, 右面における温度履歴と前面におけるそれがほぼ等しい. 後面の時間遅れは前面（右面）のそれより短い. また, 後 面と前面（右面）の時間遅れは，それぞれ，前面が加熱さ れる実験における右面と左面（後面）のそれらと等しい. これは $a_{x x}$ と $a_{y y}$ が等しくなることを示す. 表 5 と 6 に, 二 次元熱伝導における近似解を順解析とする逆解析によって 決定される温度伝導率成分とその無次元数を示す. 温度伝 導率成分とその大きさはすべて文献值よりも大きく, その 誤差は標準偏差よりも大きい. $\theta=45^{\circ}$ の大きさと $\theta=0^{\circ}$ のそれは, 標準偏差の範囲内で一致する. 表 6 の無次元温 度伝導率成分の文献值は, 標準偏差の範囲内である. よっ 
て，その大きさが試料毎の個体差により異なるものと考え られる. また, 図 10 に示寸温度履歴の解析值は観測值と 良く一致する.

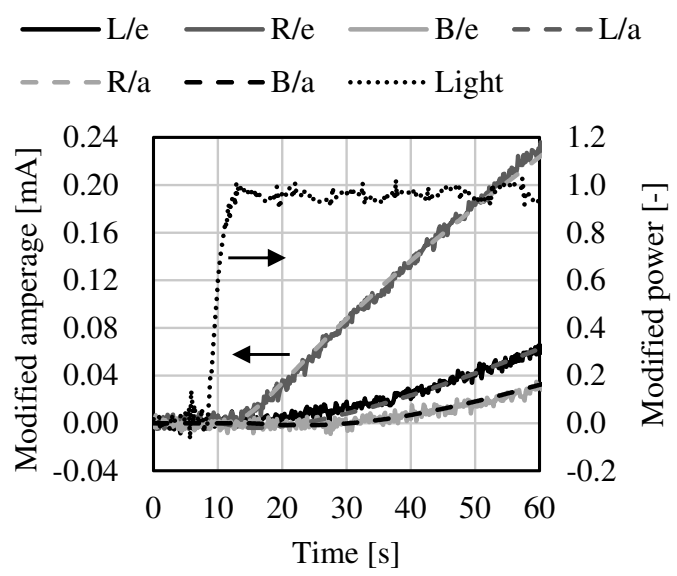

(a) When sample is heated at front surface

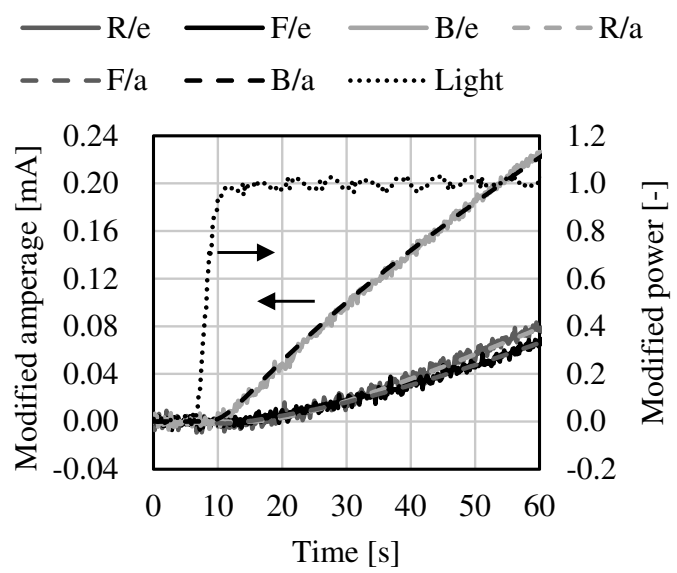

(b) When sample is heated at left side surface

Fig. 9 Modified amperage of infrared sensor and modified power of light heating as a function of time for a $\mathrm{C} / \mathrm{C}$ composite of $\theta=30$ degrees.

\section{5. 結論}

本報では, $\mathrm{Ti}$ と $\mathrm{C} / \mathrm{C}$ 複合材料に対して, 光加熱を用いた 熱伝導実験を行い, 加熱面を除く 3 面における温度履歴を 観測し, 温度伝導率測定法の健全性を検討し, 以下の結論 を得た。

\section{(1) $\mathrm{Ti} と \theta=0^{\circ}$ の $\mathrm{C} / \mathrm{C}$ 複合材料の温度伝導率を一次元熱 伝導に対する厳密解を順解析とする逆解析により決定 できることを実証した.}

(2) $\mathrm{Ti}$ と $\theta=0^{\circ}, \theta=20^{\circ}, \theta=30^{\circ}$ および $\theta=45^{\circ}$ の $\mathrm{C} / \mathrm{C}$
複合材料の二次元温度伝導率成分を二次元熱伝導に対 する近似解を順解析とする逆解析により決定できるこ とを実証した。

（3）今後, 温度伝導率の偶然誤差を小さくし, 精度を向上 させるため，赤外線温度計における観測視野の位置精 度と近似解の精度を改良する必要がある.

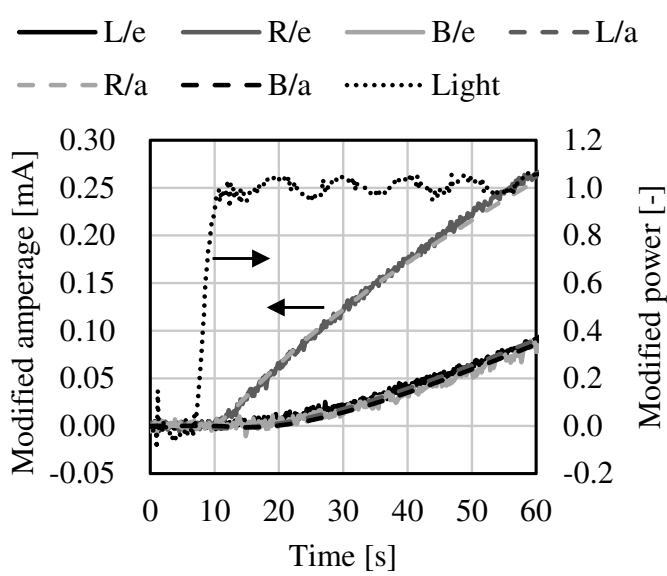

(a) When sample is heated at front surface

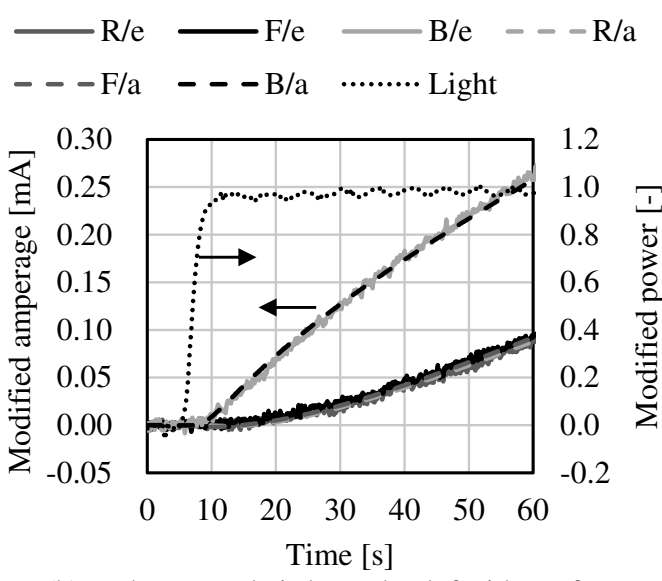

(b) When sample is heated at left side surface

Fig. 10 Modified amperage of infrared sensor and modified power of light heating as a function of time for a $\mathrm{C} / \mathrm{C}$ composite of $\theta=45$ degrees.

\section{NOMENCLATURE}

$t \quad:$ time, $\mathrm{s}$

$(x, y) \quad$ : coordinates in width and thickness, $\mathrm{m}$

$T \quad$ : temperature, $\mathrm{K}$

a : thermal diffusivity, $\mathrm{m}^{2} / \mathrm{s}$

a : thermal diffusivity tensor of 2 dimensions, $\mathrm{m}^{2} / \mathrm{s}$ 
$a_{x y} \quad:$ thermal diffusivity coefficients, $\mathrm{m}^{2} / \mathrm{s}$

$k \quad:$ thermal conductivity, $\mathrm{W} /(\mathrm{m} \cdot \mathrm{K})$

$l_{x} \quad$ : width of sample, $\mathrm{m}$

$l_{y} \quad:$ thickness of sample, $\mathrm{m}$

$\boldsymbol{q}_{h} \quad$ : surface heat flux, $\mathrm{W} / \mathrm{m}^{2}$

$q_{0} \quad:$ intensity of $\boldsymbol{q}_{h}, \mathrm{~W} / \mathrm{m}^{2}$

$q_{e} \quad$ : observed profile of $\boldsymbol{q}_{h}$ as a function of $t$,

$\rho \quad:$ density, $\mathrm{kg} / \mathrm{m}^{3}$

$c \quad:$ specific heat, $\mathrm{kJ} /(\mathrm{kg} \cdot \mathrm{K})$

$\boldsymbol{q} \quad$ : heat flux, $\mathrm{W} / \mathrm{m}^{2}$

$j \quad$ : unit parallel vector to $y$ axsis,

$n$ : unit perpendicular vector on surface,

$\tau \quad:$ time for integral, $\mathrm{s}$

$\psi \quad$ : coordinate in thickness for integral, $\mathrm{m}$

$G(y, t ; \psi, \tau)$ : Green function, $\mathrm{K}$

$u\left(x, l_{x}\right)$ : unit step function,

$\delta(y)$ : delta function,

\section{参考文献}

[1] H. S. Carslaw, J. C. Jaeger; "Conduction of Heat in Solids", 2nd ed. (1959) 38, 359, Oxford University Press, New York.

[2] 横田仁志, 太田弘道, 柴田浩幸; 「複合材料の有効熱伝 導率導出に関する数值シミュレーション」, 熱物性, 13 (1999) 240-245.

[3] 佐藤裕, 大竹邦彦, 嶋田徹, 佐藤英一; 「ロケットノズ ル材料の熱拡散率評価」, 熱物性, 17 (2003) 199-204.

[4] 入澤寿平, 西村和己, 山本徹也, 牧野雄太, 田邊靖博; 「炭素系廃棄物を用いた C/C コンポジットの熱伝導 性」, 第 39 回日本熱物性シンポジウム講演論文集 (2018) 127-129.

[5] 栗原理也, 長野方星; 「ロックイン・サーモグラフィを 用いた高熱伝導炭素系複合材料の熱的異方性評価装置 の開発」，熱物性, 28 (2014) 82-88.

[6] 根本栄治; 「レーザパルス状点熱源加熱法を用いた異 万性非定常対数法による 2 次元雲母材の主軸熱拡散率 および主軸角の同時分離測定」, 第 22 回日本熱物性シ ンポジウム講演論文集 (2001) 419-421.

[7]「熱物性資料集断熱材編」, 日本熱物性研究会編 (1983) 15，㑣養賢堂.

[8] 荒木信幸, 中村佳央, 高野義昭; 「ステップ状加熱法に よる溶融塩の熱拡散率測定におけるふく射伝熱の影 響」, 第 11 回日本熱物性シンポジウム講演論文集 (1990) 263-266.

[9] J. A. Nelder, R. Mead; “A simplex method for function minimization", The Computer Journal, 7 (1965) 308313.

[10] 矢川元基;「流れと熱伝導の有限要素法入門」(1992) 103，(株培風館.

[11]「伝熱工学資料改訂第4 版」, 日本機械学会編 (1994) 316, (株丸善.

[12] 菅原利夫, 田中義和; 「炭素繊維強化炭素複合材料 (C/C コンポジット)」, 繊維学会誌, 49(5) (1993) 183189.

[Received Mar. 2, 2020, Accepted July 10, 2020] 